\title{
First Report of Leaf Blight on Ficus religiosa caused by Phyllosticta sp.
}

\section{Pankaj Sharma ${ }^{1 *}$ N. Singh ${ }^{2}$ and O.P. Verma ${ }^{3}$}

${ }^{1}$ Department of Plant Pathology, Maharana Pratap University of Agriculture and Technology, Udaipur 313 001, India Present address: Directorate of Rapeseed-Mustard Research (ICAR), Bharatpur 321 303, India

2 Potato Research Station, S.D. Agriculture University, Deesa, Gujarat, India

${ }^{3} 61 / 130$, Pratap Nagar Housing Board, Sanganer, Jaipur 302 033, India

\begin{abstract}
A fungal leaf blight disease symptom was observed on Ficus religiosa. The spots were circular to irregular and dark reddish brown in colour. Several spots coalesced to each other and cover large portions on the leaf, which gave a blighted appearance. The fungus after purification the fungus was identified as Phyllosticta sp. This is the first report of leaf blight on F. religiosa caused by Phyllosticta sp. from India.
\end{abstract}

\section{Keywords: Leaf blight; Ficus religiosa; Phyllosticta sp.}

Ficus religiosa commonly known as Pipal in hindi and Pippala vrksha in Sanskrit. It is an ever green tree of up to $30 \mathrm{~m}$. of height. The bark of trunks and older branches are brown and smooth. Branchlets are glabrous and leaves are ovate. Roots, bark-skin, fruits and leaves of F. Religiosa have great medicinal value. Root bark is good for stomatitis and for cleaning ulcers. It is also used as astringent in patients with leucorrhoea and it promotes granulations. The roots are chewed to prevent gum disease. Fruits are laxative and promote digestion. Ripe fruits are alexipharmic (an antidote or defensive remedy against poison, venom or infection), are good for foul taste, thirst and heart disease. The leaves alone are used to treat constipation. The leaves and young shoots together are purgative [1].

During post-rainy season 2008, a survey in Ramniwas public garden, Jaipur, leaves of F. religiosa were found affected by a leaf spot disease. Initially the lesions are circular or oval usually less than $5 \mathrm{~mm}$. Dark reddish brown lesions starting at the leaf margin and progressing inward. As the disease progresses, lesions became irregular and when severe infection occurs, several spots coalesced to each other and cover large portions on the leaf, which gave a blighted appearance (Figure 1). For isolation, leaves were cut into pieces of $2 \mathrm{~mm} 2$, sterilized in $0.1 \% \mathrm{HgCl} 2$ for $1 \mathrm{~min}$ and placed on Potato Dextrose Agar (PDA) plates containing $100 \mu \mathrm{g} / \mathrm{ml}$ streptomycin. One week later, the mycelia growing from pieces of leaves were transferred onto another PDA plate. Colony on PDA grew slowly, attaining approximately $50 \mathrm{~mm}$ diameter after 15 days. Colonies were circular, olivaceous greenish to olivaceous black, often with darker concentric zones. The aerial mycelium was sparse, white and floccose. Conidiomata were pycnidial, globose or subglobose, immersed or semi-immersed. Also, conidia were ellipsoid to ovoid, hyaline, with rounded ends, unicellular, thin, smooth-walled, pomiform, subcylindrical to subglobose and colourless. Measurements of conidia were 10-13 $\times 7-11 \mu \mathrm{m}$. The fungus was morphologically identified as Phyllosticta sp. [2]. This identification was also confirmed by Fungal Identification Service, Mycology and Plant Pathology Group, Agharkar Research Institute, Pune, India (ref no. OP 94).

To perform pathogenicity assays, a conidial suspension (106 conidia per $\mathrm{ml}$ ), collected from PDA cultures was used to spray on leaves by using a manual atomizer until conidial suspension run off. Inoculated leaves were covered with large plastic bags to maintain high humidity for two days. Control leaves were similarly treated with only sterile distilled water. After 10 to 15 days, inoculated leaves showed infection symptoms resembling those observed on F. religiosa naturally infected. Re-isolation of inoculated leaves developed Phyllosticta sp. growth on PDA while control leaves did not develop any symptoms.

The genus Phyllosticta contains saprophytic, endophytic and plant pathogenic species. Pathogenic species cause economically significant diseases in a wide range of plant species such as fruits, vegetables, cereals, and forage crops $[3,4]$. To our knowledge, this is the first report of leaf blight on F. religiosa caused by Phyllosticta sp.

\section{References}

1. Joy PP, Thomas J, Mathew S, Skaria BP (2001) Medicinal Plants In: Bose TK, Kabir J, Das P \& Joy PP (ed.) Tropical Horticulture 2: 449-632.

2. Van der Aa HA (1973) Studies in Phyllosticta I Stud Mycol 5:1-110

3. Fisher PJ, Petrini O, Petrinf LE, Sutton BC (1994) Fungal endophytes from the leaves and twigs of Quercus ilex L. from England, Majorca and Switzerland. New Phytol 127: 133-137.

4. Jamaluddin, Goswami MG, Ojha BM (2004) Fungi of India. Scientific Publishers (India) 112-114.

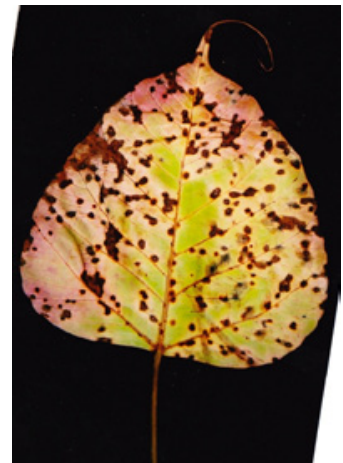

Figure 1: Leaf blight symptoms on Ficus religiosa caused by Phyllosticta sp.
*Corresponding author: Pankaj Sharma, Department of Plant Pathology, Maharana Pratap University of Agriculture and Technology, Udaipur 313 001, India Present address: Directorate of Rapeseed-Mustard Research (ICAR), Bharatpur 321 303, India, E-mail: pksvirus@gmail.com

Received April 25, 2011; Accepted June 27, 2011; Published July 07, 2011

Citation: Sharma P, Singh N, Verma OP (2011) First Report of Leaf Blight on Ficus religiosa caused by Phyllosticta sp. J Plant Pathol Microbiol 2:106. doi:10.4172/2157-7471.1000106

Copyright: ( 2011 Sharma P, et al. This is an open-access article distributed unde the terms of the Creative Commons Attribution License, which permits unrestricted use, distribution, and reproduction in any medium, provided the original author and source are credited. 